\title{
ESTIMASI PERFORMA SISTEM PROPULSI PADA KAPAL DENGAN TIPE CONTROLLABLE PITCH PROPELLER
}

\section{ESTIMATION OF PROPULSION SYSTEM PERFORMANCE ON CONTROLLABLE PITCH PROPELLER VESSEL}

\author{
Dwitya Harits Waskito ${ }^{1}$ * \\ ${ }^{1}$ Balai Teknologi Survei Kelautan, Badan Pengkajian dan Penerapan Teknologi (BPPT), \\ Jl. MH. Thamrin No. 8, Jakarta \\ *E-mail: dwitya.harits@bppt.go.id
}

\begin{abstract}
ABSTRAK
Perhitungan performa sistem propulsi sebuah kapal secara real-time sangat penting untuk dapat mengukur kualitas dan efisiensi dari komponen yang ada pada sistem propulsi itu sendiri. Metode yang telah dikembangkan berpusat kepada perhitungan pada kapal dengan tipe propeller Fixed Pitch Propeller, sedangkan untuk kapal dengan tipe Controllable Pitch Propeller metode tersebut kurang tepat jika digunakan karena perbedaan pitch pada setiap kecepatan. Oleh karena itu dibutuhkan suatu metode perhitungan analitik yang dapat digunakan secara efisien, mudah, akurat, dan dapat dilakukan pada saat kapal berlayar. Metode yang digunakan adalah mendapatkan data dari pitch pada propeller pada masing - masing kecepatan dimana dari data pitch tersebut dapat digunakan untuk mendapatkan nilai estimasi performa sistem propulsi dengan menggunakan metode engine- propeller matching. Metode perhitungan yang dilakukan pada tulisan ini dapat juga digunakan sebagai pembanding terhadap kondisi sistem propulsi kapal terkini dengan kondisi propulsi kapal pada saat commissioning.
\end{abstract}

Kata Kunci: propulsi, controllable pitch propeller, pitch, propeller, kapal riset

\begin{abstract}
[Estimation of Propulsion System Performance on Controllable Pitch Propeller Vessel] The calculation of ship propulsion performance with real-time data is really important to measure the quality and efficiency of ship propulsion system. Currently, the calculation method that being developed is more suitable for ship with Fixed Pitch Propeller system. However, that method is insignificant if it is used on ship with Controllable Pitch Propeller system, since the Controllable Pitch Propeller has the difference on pitch for each speed. Therefore, there is a demand for an analytical calculation for ship with Controllable Pitch Propeller system that efficient, user friendly, and accurate. The method that will be used in this paper is by obtaining the geometric pitch data in when the ship is on transit. After the pitch data is obtained, it can be used for estimating the propulsion system performance through the engine-propeller matching method. Calculation method that developed in this paper also can be utilized as a benchmark tools for comparing ship propulsion system performance.
\end{abstract}

Keywords: propulsion, controllable pitch propeller, pitch, propeller, research vessel

\section{PENDAHULUAN}

Pelayaran dunia berkontribusi terhadap 3.1\% emisi gas $\mathrm{CO}_{2}$ (International Maritime Organization, 2015) dan berdasarkan angka tersebut pada tahun 2018, IMO telah menetapkan untuk menurunkan angka emisi tersebut menjadi $50 \%$ pada tahun 2050 mendatang. Tujuan tersebut akan sangat bergantung terhadap kemampuan dan teknologi untuk mengukur dan menganalisa konsumsi bahan bakar dan performa dari sistem propulsi pada suatu kapal. Hal yang dapat dilakukan adalah mengukur secara 
akurat konsumsi bahan bakar dari kapal pada setiap waktu tertentu secara real-time. Untuk mendapatkan nilai konsumsi bahan bakar, dibutuhkan perhitungan performa dan efisiensi dari mesin kapal secara real-time pada saat berlayar. Namun pada kondisi saat ini pada kapal-kapal niaga pada umumnya, jarang sekali dilakukan pengukuran, perhitungan, dan analisa terhadap performa dari mesin kapal.

Salah satu penyebab minimnya dilakukan adalah terkendalanya kemampuan sumber daya manusia dan infrastruktur. Beberapa kapal niaga pada umumnya telah dipasang sistem automatisasi dan digitalisasi untuk melakukan perhitungan performa permesinan kapal. Hal ini berbeda dengan yang ada pada kapal - kapal konvensional atau kapal yang telah berusia tiga puluh tahun lebih, dimana belum dilengkapi dengan sistem otomatisasi dan digitalisasi untuk perhitungan performa dan efisiensi permesinan kapal.

Untuk menyelesaikan permasalahan tersebut, perhitungan performa permesinan kapal dapat dilakukan secara analitis dengan melakukan perhitungan yang telah dilakukan peneliti lain dengan mengintegrasikan nilai dari berbagai hambatan yang dialami oleh kapal (angin, gelombang dan added resistance) (Tsujimoto et al., 2009; Zhao et al., 2015) dan estimasi daya yang dilakukan dengan memprediksi penurunan kecepatan sehingga mendapatkan nilai aktual dari daya mesin (Chuang dan Steen, 2011). Permasalahan selanjutnya akan muncul, jika jenis dari propeller suatu kapal adalah Controllable Pitch Propeller (CPP). Dimana pada CPP, rpm dari poros propeller adalah konstan. Oleh karena itu, estimasi nilai performa permesinan kapal dengan propeller tipe Fixed Pitch Propeller (FPP) tidak akurat jika digunakan pada CPP. Dibutuhkan suatu metode perhitungan secara analitik untuk dapat mengestimasi performa mesin kapal dengan tipe propeller CPP yang mudah dilakukan, hemat waktu, dan dapat dilakukan secara real-time. Pada tulisan ini, akan dilakukan perhitungan untuk mendapatkan nilai dari daya sistem propulsi yang ada pada propeller dengan jenis CPP dengan menggunakan pendekatan yang berbeda dengan perhitungan kapal dengan propeller jenis FPP.

\section{METODOLOGI}

Kapal yang dianalisa sistem propulsinya adalah Kapal Riset (KR.) Baruna Jaya IV milik Badan Pengkajian dan Penerapan Teknologi (Gambar 1), dengan ukuran utama seperti terlihat pada Tabel 1.

Tabel 1. Ukuran utama KR. Baruna Jaya IV.

\begin{tabular}{lc}
\hline \multicolumn{1}{c}{ Spesifikasi } & Nilai \\
\hline Panjang Kapal sepanjang garis air $(L w l)$ & $55 \mathrm{~m}$ \\
Lebar $(B)$ & $12 \mathrm{~m}$ \\
Draft $(T)$ & $4.15 \mathrm{~m}$ \\
Displacement $(\Delta)$ & $1515 \mathrm{ton}$ \\
Koefisien blok $\left(C_{b}\right)$ & 0.489 \\
Kecepatan servis $\left(V_{s}\right)$ & 8 knots \\
\hline
\end{tabular}




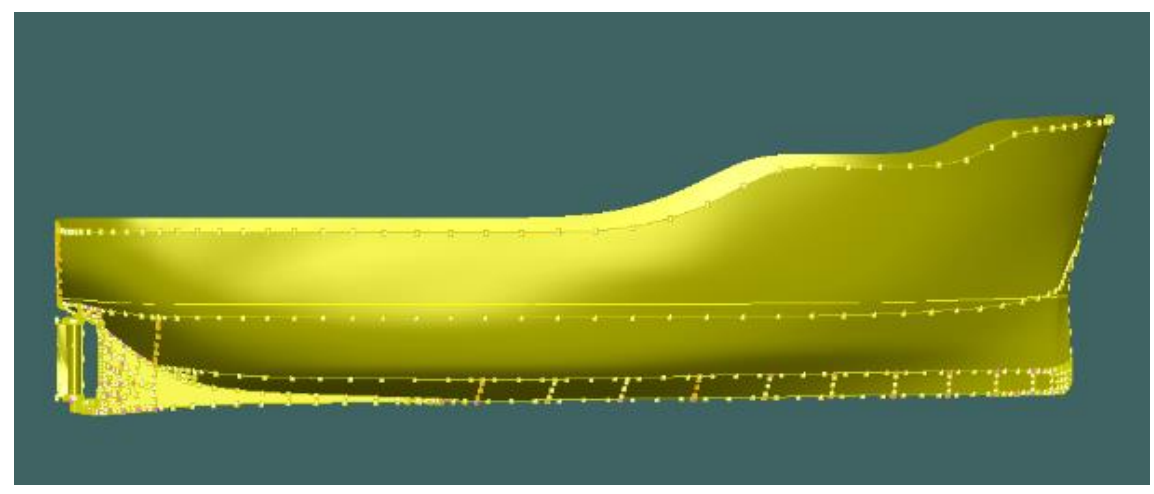

Gambar 1. Model Maxsurf Kapal Riset (KR.) Baruna Jaya IV BPPT (Waskito, 2018).

Sedangkan spesifikasi dari mesin utama dan propeller pada KR Baruna Jaya IV dapat terlihat pada Tabel 2.

Tabel 2. Spesifikasi mesin utama dan propeller KR Baruna Jaya IV.

\begin{tabular}{lc}
\hline \multicolumn{1}{c}{ Komponen Permesinan } & Spesifikasi \\
\hline Mesin utama & \\
(2x Niigata Pielstick 5PA5L) & \\
- Daya per mesin & $1100 \mathrm{HP}$ \\
- Rpm mesin & 850 \\
\hline Propeller & \\
- Daya aktual & $1618 \mathrm{~kW}$ \\
- rpm & 240 \\
- Diameter propeller (DP) & $2.5 \mathrm{~m}$ \\
- Propeller blade (n) & 4 \\
- Pitch rata - rata (Pavg) & $2.056 \mathrm{~m}$ \\
- Blade Area Ratio (BAR) & 0.503 \\
\hline
\end{tabular}

Data yang akan digunakan dalam perhitungan didapatkan dari data navigasi pada dua pelayaran berbeda menggunakan KR Baruna Jaya IV. Cruise1 dilakukan pada Maret 2018 dengan trayek Jakarta - Pangandaran dengan kondisi mesin belum dilakukan overhaul sedangkan Cruise 2 dilakukan pada Juli 2019 dengan trayek Jakarta Kendari dengan kondisi mesin sudah dilakukan overhaul.

\subsection{Perhitungan Pitch}

Perhitungan performa sistem propulsi untuk kapal dengan tipe CPP secara analitis berbeda dengan kapal dengan tipe propeller FPP. Pada umumnya kapal dengan tipe CPP mempunyai rpm mesin dan poros yang konstan. Pengaturan kecepatan kapal dilakukan dengan perubahan pitch set point $\left(P_{\text {set }}\right)$ yang dilakukan oleh officer di anjungan. Oleh karena itu propeller mengalami fenomena pitch $(P)$ yang fluktuatif dikarenakan perubahan pitch angle set point $\left(P_{\text {set }}\right)$. Nilai dari pitch sebetulnya sudah didapatkan dari pabrik propeller tersebut, namun dengan adanya perubahan nilai pitch pada saat pelayaran, dibutuhkan metode untuk mengestimasi nilai pitch pada kecepatan tertentu. Pitch atau geometric pitch dapat diartikan sebagai jarak yang ditempuh (dalam 
meter) dalam sekali putaran. Dengan pengertian tersebut, nilai dari geometric pitch dapat dihitung dengan persamaan:

$P=\frac{D_{1 \min }}{n}$

Dimana $D_{1 \min }$ adalah jarak yang ditempuh kapal (dalam meter) pada satu menit sedangkan $n$ adalah rpm propeller.

\subsection{Hambatan Kapal}

Dalam perhitungan sistem propulsi, langkah pertama yang dilakukan adalah menghitung hambatan kapal terkini pada KR Baruna Jaya IV berdasarkan metode yang dikembangkan oleh (Holtrop dan Mennen, 1982) dengan persamaan:

$R_{T}=R_{F}\left(1+k_{1}\right)+R_{A P P}+R_{W}+R_{T R}+R_{A}$

Dimana $R_{T}$ adalah hambatan total kapal, $R_{F}$ adalah hambatan gesek karena pergerakan kapal di air, $\left(1+k_{1}\right)$ adalah faktor bentuk dari lambung kapal. $R_{A P P}$ adalah nilai dari hambatan appendages, $R_{W}$ adalah nilai dari estimasi awal terhadap hambatan gelombang, $R_{T R}$ adalah nilai hambatan dikarenakan transorm stern yang berada di bawah garis air, dan $R_{A}$ adalah nilai hambatan korelasi antara kapal model dan skala penuh. Perhitungan nilai hambatan dilakukan dengan menggunakan software Maxsurf Resistance.

\subsection{Efisiensi Komponen Sistem Propulsi}

Pada saat kapal berlayar, terdapat interaksi antara lambung dengan sistem propulsi (propeller) yang dapat mempengaruhi efisiensi dan desain dari sistem tersebut. Komponen pertama adalah wake yang merupakan efek dari aliran air yang menuju ke propeller yang disebabkan oleh bentuk dari lambung kapal. Wake ditandai dengan wake fraction atau $w_{t}$ (Molland et al., 2011).

$$
w_{t}=0.5 C_{B}-0.05
$$

Dimana $C_{B}$ adalah blok koefisien dari kapal. Dengan adanya pengaruh dari wake pada buritan maka kecepatan kapal berkurang menjadi kecepatan advanced $\left(V_{a}\right)$ yang dapat dihitung dengan persamaan:

$$
V_{a}=V_{s}\left(1-w_{t}\right)
$$

\subsection{Perhitungan Delivered Power $\left(\mathbf{P}_{\mathbf{D}}\right)$}

Untuk menganalisa performa sistem propulsi, tentunya harus didapatkan nilai dari daya salah satu komponen sistem propulsi baik itu mesin utama, poros, maupun propeller. Dalam perhitungan ini output yang dihasilkan adalah nilai dari Delivered 
Power $\left(P_{D}\right)$. $P_{D}$ adalah daya yang harus dikeluarkan oleh propeller untuk menggerakkan kapal dengan kecepatan dan pada hambatan tertentu. Nilai dari $P_{D}$ didapatkan menggunakan persamaan:

$$
P_{D}=2 \pi n Q
$$

Dimana $Q$ adalah torsi yang dihasilkan oleh putaran shaft propeller. Nilai $Q$ didapatkan dari persamaan:

$$
Q=K_{Q} \rho n^{2} D^{5}
$$

$K_{Q}$ adalah koefisien non-dimensional dari torsi. Nilai dari $K_{Q}$ didapatkan dari metode engine-propeller matching dengan menggunakan diagram Wageningen B 4.50. Diagram tersebut dapat digunakan untuk kapal tipe FPP dan CPP (Dang et al., 2013). Input dari diagram tersebut dari sumbu $\mathrm{x}$ adalah nilai dari $J$ (Propeller advance ratio) yang didapatkan dari persamaan:

$J=\frac{V_{a}}{n D}$

Nilai dari $J$ dipertemukan secara vertikal dengan nilai $P / D$ yang ditandai dengan garis putus-putus. Dimana $\mathrm{P}$ adalah nilai pitch yang telah didapatkan dari data navigasi dan $\mathrm{D}$ adalah diameter propeller. Setelah itu titik pertemuan tersebut ditarik ke sumbu y untuk menentukan nilai dari $K_{Q}$ dimana nilai tersebut akan digunakan dalam perhitungan $P_{D}$ berdasarkan persamaan (5).

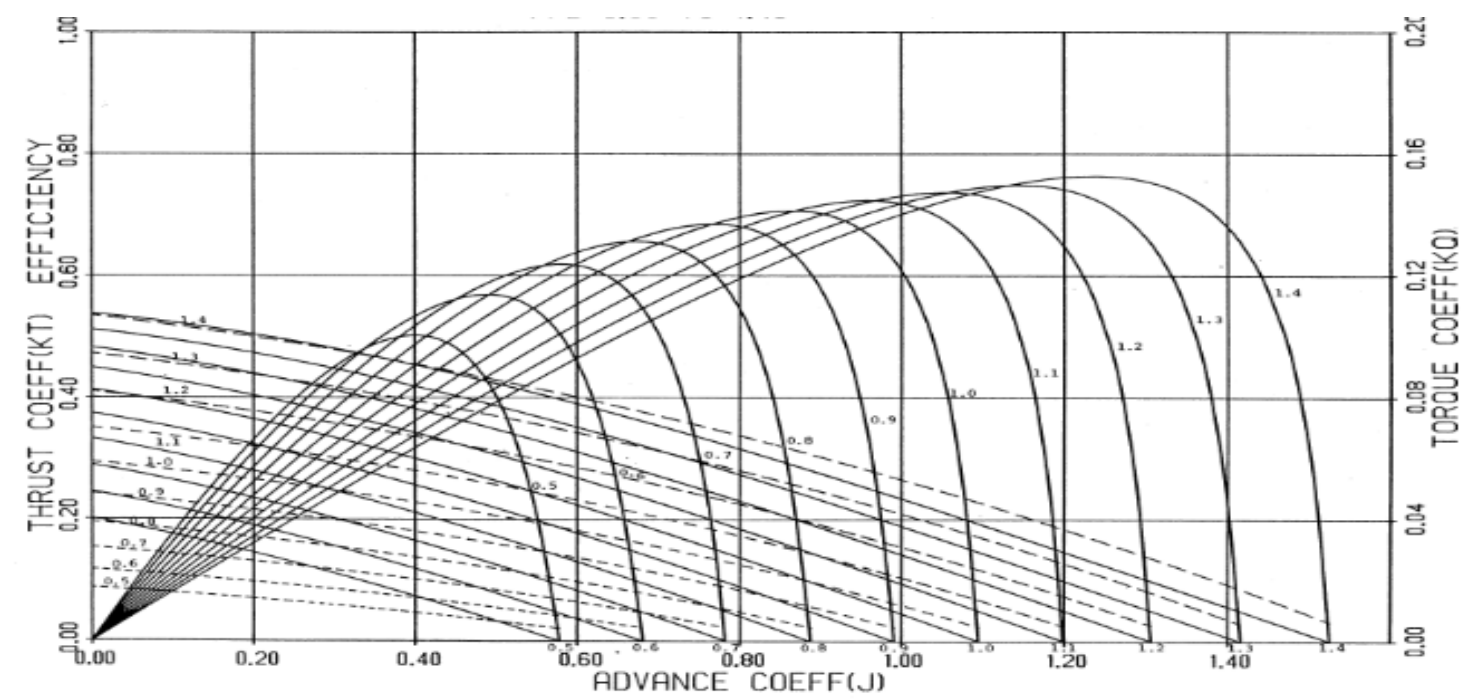

Gambar 2. Diagram Wageningen B Series BAR 0.5, dengan 4 daun propeller (Bernitsas et al., 1981). 


\section{HASIL DAN PEMBAHASAN}

\subsection{Hasil Perhitungan Pitch}

Nilai kecepatan pada Gambar 3 adalah nilai kecepatan rata-rata dalam satu menit $\left(V_{\text {avg }}\right)$ pada jarak tertentu $\left(D_{\text {lmin }}\right)$ dimana jarak tersebut digunakan dalam perhitungan pitch berdasarkan persamaan (1). Terdapat perbedaan nilai pitch yang disebabkan karena kondisi mesin yang berbeda pada kedua pelayaran tersebut. Pada Cruise2, nilai pitch dan kecepatan maksimum yang dicapai lebih tinggi karena kondisi mesin telah dilakukan overhaul sehingga kemampuan dan performa mesin meningkat dibanding pada saat Cruise1.

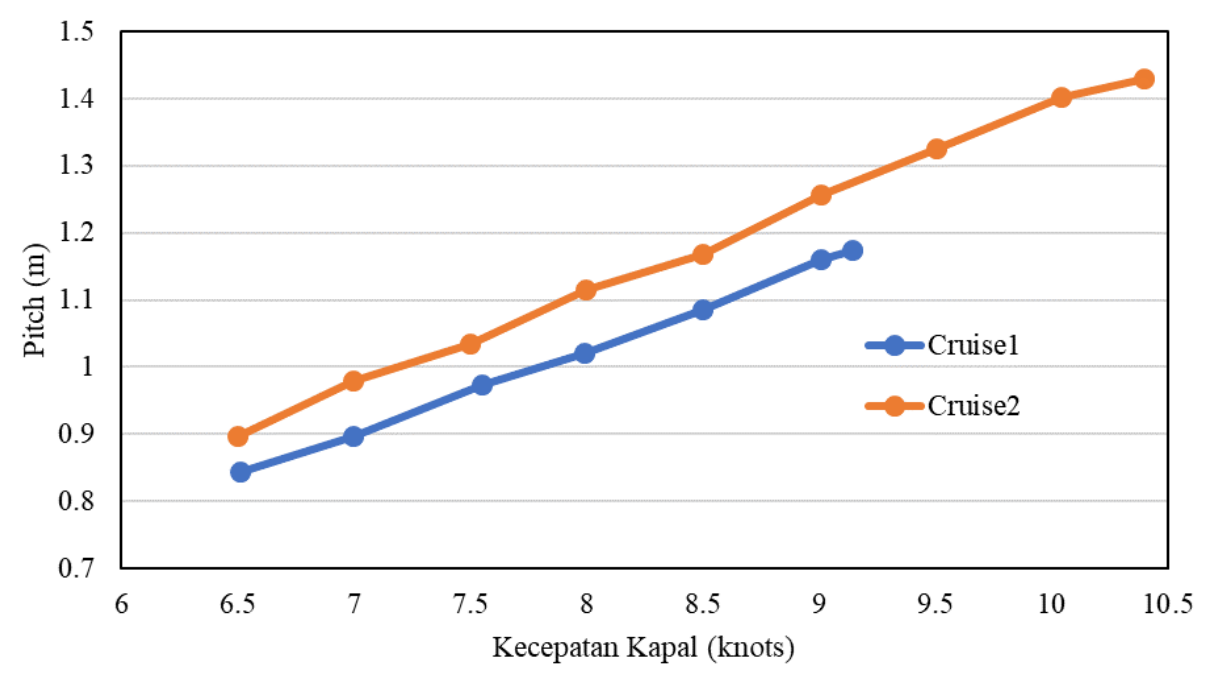

Gambar 3. Nilai dari pitch pada berbagai kecepatan kapal.

Dengan nilai pitch yang tinggi, jarak yang ditempuh semakin panjang dan kecepatan kapal tentu akan semakin tinggi, akan tetapi pada Gambar 3 terlihat pada kecepatan yang sama pada kedua pelayaran, nilai dari pitch dapat berbeda. Untuk melakukan analisa mendalam mengenai pengaruh kecepatan terhadap pitch, dilakukan pengambilan data nilai pitch pada berbagai kecepatan yang sama dengan variasi kecepatan 7-10 knots pada Cruise2.

Nilai dari $\left(V_{a v g}\right)$ diambil dari beberapa sampel dengan waktu yang berbeda pada Cruise 2. Berdasarkan Gambar 4 dan 5 dapat dilihat bahwa nilai dari pitch dapat berbeda pada kecepatan yang sama, hal ini disebabkan karena pada saat kapal mencapai kecepatan tertentu, kondisi lingkungan (angin, arus, dan gelombang) yang dialami kapal berbeda-beda sehingga menyebabkan perbedaan pitch yang dihasilkan. Selain itu perbedaan nilai pitch pada suatu kecepatan tertentu disebabkan karena performa mesin yang fluktuatif yang dipicu oleh kondisi pendinginan pada mesin, dan ketahanan panas dari suku cadang yang ada pada cylinder head. Nilai margin perbedaan pitch terbesar adalah pada kecepatan 8 knots yaitu sebesar $0.084 \mathrm{~m}(7.54 \%)$. 

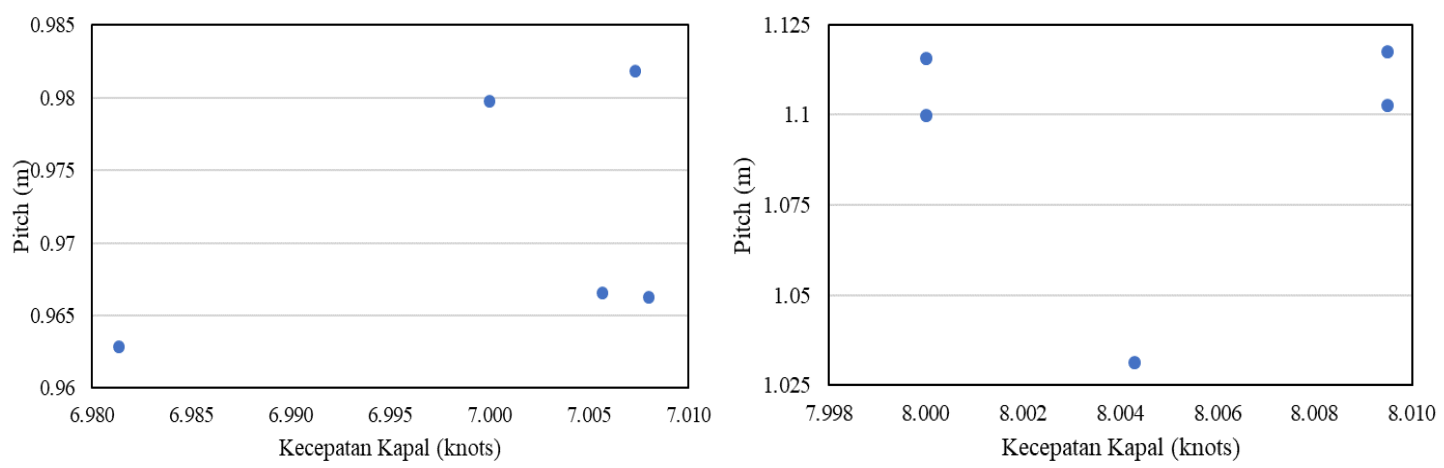

Gambar 4. (Kiri) Nilai dari pitch pada berbagai kecepatan kapal dalam batas 7 knots. (Kanan) Nilai dari pitch pada berbagai kecepatan kapal dalam batas 8 knots.
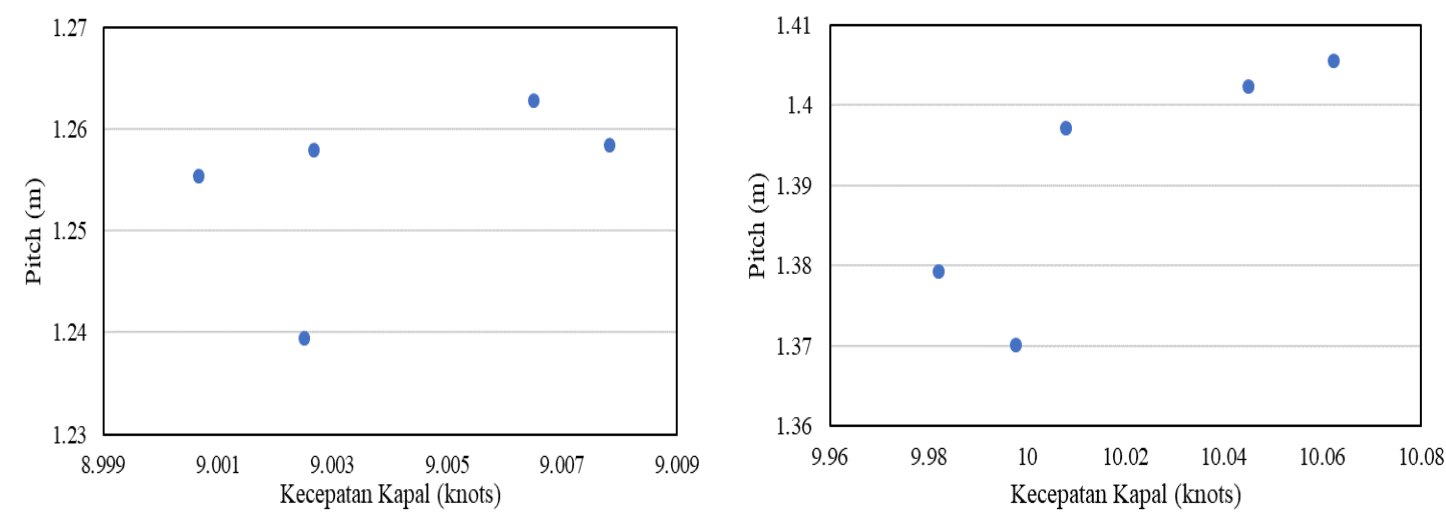

Gambar 5. (Kiri) Nilai dari pitch pada berbagai kecepatan kapal dalam batas 9 knots. (Kanan) Nilai dari pitch pada berbagai kecepatan kapal dalam batas 10 knots.

\subsection{Hasil perhitungan Delivered Power}

Nilai dari $K_{Q}$ berdasarkan metode engine-propeller matching pada kedua cruise adalah seperti dalam Tabel 3 dan 4.

Tabel 3. Nilai koefisien perhitungan $P_{D}$ pada Cruise1.

\begin{tabular}{cccc}
\hline $\boldsymbol{V}$ (knots) & $\boldsymbol{P} / \boldsymbol{D}$ & $\boldsymbol{J}$ & $\boldsymbol{K}_{\boldsymbol{Q}}$ \\
\hline 6.51 & 0.34 & 0.27 & 0.0034 \\
7.00 & 0.36 & 0.29 & 0.0044 \\
7.55 & 0.39 & 0.31 & 0.0059 \\
8.00 & 0.41 & 0.33 & 0.0068 \\
8.50 & 0.43 & 0.35 & 0.0082 \\
9.01 & 0.46 & 0.37 & 0.0096 \\
9.15 & 0.47 & 0.38 & 0.0102 \\
\hline
\end{tabular}

Nilai $P_{D}$ pada kedua cruise yang dikalkulasi menggunakan persamaan (5) digambarkan pada grafik Gambar 6. 
Tabel 4. Nilai koefisien perhitungan $P_{D}$ pada Cruise2.

\begin{tabular}{cccc}
\hline $\boldsymbol{V}$ (knots) & $\boldsymbol{P} / \boldsymbol{D}$ & $\boldsymbol{J}$ & $\boldsymbol{K}_{\boldsymbol{Q}}$ \\
\hline 6.50 & 0.36 & 0.27 & 0.0044 \\
7.00 & 0.39 & 0.29 & 0.0058 \\
7.50 & 0.41 & 0.31 & 0.0071 \\
8.00 & 0.45 & 0.33 & 0.0083 \\
8.50 & 0.47 & 0.35 & 0.0100 \\
9.01 & 0.50 & 0.37 & 0.0108 \\
9.51 & 0.53 & 0.39 & 0.0114 \\
10.05 & 0.56 & 0.42 & 0.0121 \\
10.40 & 0.57 & 0.43 & 0.0125 \\
\hline
\end{tabular}

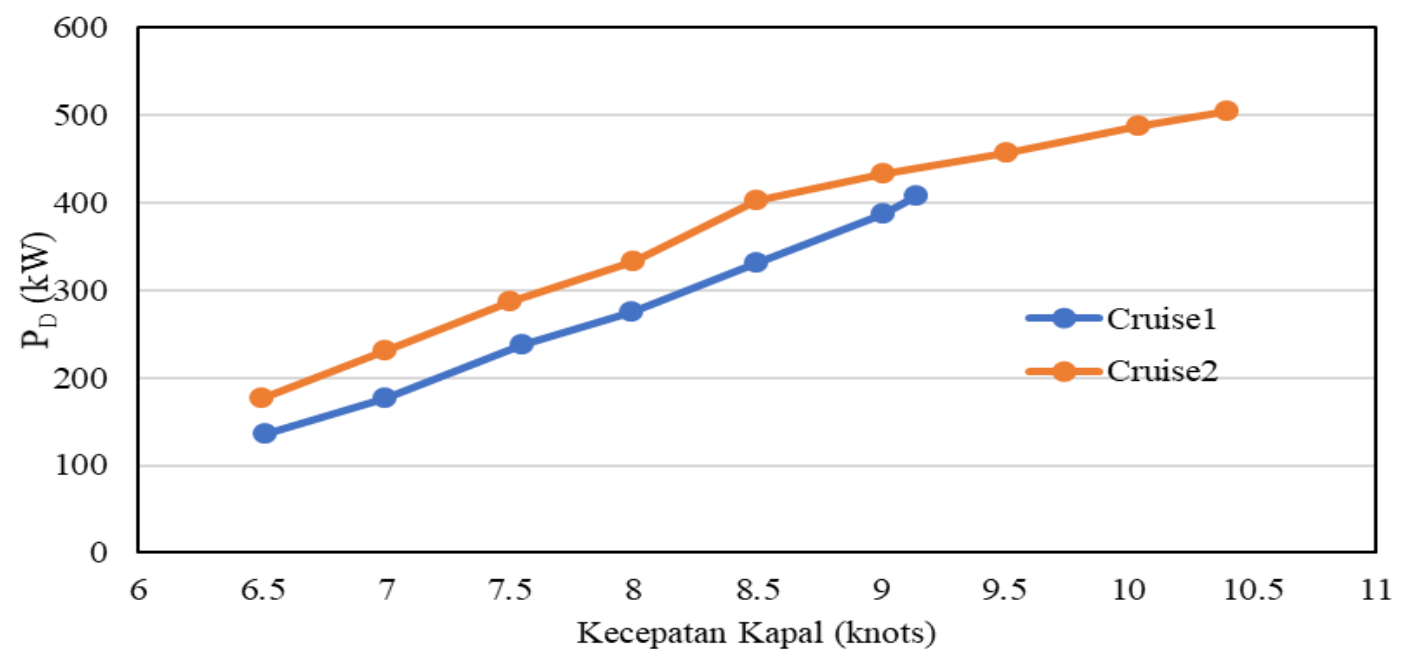

Gambar 6. Nilai $P_{D}$ pada berbagai kecepatan.

Dari gambar di atas didapatkan bahwa kecenderungan grafik dari nilai $P_{D}$ mirip dengan kecenderungan grafik dari nilai pitch Gambar 3, yaitu meningkat secara linear. Oleh karena itu perhitungan nilai $P_{D}$ dapat digunakan sebagai estimasi perhitungan nilai sistem propulsi pada sebuah kapal. Terlebih lagi, dengan nilai $P_{D}$ yang didapat maka dapat dilakukan analisa lebih lanjut pada sistem propulsi, seperti efisiensi performa mesin, efisiensi poros, dan perhitungan konsumsi bahan bakar sehingga setiap kapal mempunyai sistem dan mekanisme perhitungan performa secara real-time yang dapat membantu dalam menganalisa kondisi dari kapal.

Akan tetapi, perlu diperhatikan bahwa terdapat beberapa keterbatasan dalam perhitungan antara lain: pada penentuan nilai $K_{Q}$ dengan menggunakan diagram Wageningen B Series, nilai dari $P / D$ berada di luar grafik sehingga harus dilakukan ekstrapolasi untuk mendapatkan titik temu dengan kurva $J$ dimana hal ini yang dapat menyebabkan ketidaksempurnaan hasil dari perhitungan. Perlu dilakukan perhitungan engine-propeller matching untuk kapal dengan kriteria kecepatan rendah dan sedang dengan nilai $P / D$ yang rendah. Selain itu, perbedaan nilai pitch pada satu kecepatan tertentu juga dapat menyebabkan kesalahan perhitungan. 


\subsection{Penilaian Performa Sistem Propulsi KR Baruna Jaya IV}

Untuk menilai performa sistem propulsi dari kapal secara kualitatif, hasil dari perhitungan pitch, $K_{Q}$, dan $P_{D}$ pada Cruise1 dibandingkan dengan performa sistem propulsi kapal pada saat commissioning (kapal telah selesai dibangun). Data pitch maksimum pada saat commissioning didapatkan dari buku manual propeller Renou Dardel untuk KR Baruna Jaya IV. Setelah itu dilakukan perhitungan engine-propeller matching untuk mendapatkan nilai $P_{D}$ pada saat commissioning. Data hasil perhitungan tertera pada Tabel 5.

Tabel 5. Perbandingan performa sistem propulsi antara kondisi terkini kapal dengan kondisi pada saat commissioning.

\begin{tabular}{lccccc}
\hline & $\begin{array}{c}\mathbf{V}_{\mathbf{m a x}} \\
(\mathbf{k n o t s})\end{array}$ & $\begin{array}{c}\text { Pitch } \\
(\mathbf{m})\end{array}$ & $\mathbf{P} / \mathbf{D}$ & $\mathbf{K}_{\mathbf{Q}}$ & $\begin{array}{c}\mathbf{P}_{\mathbf{D}} \\
(\mathbf{k W})\end{array}$ \\
\hline Cruise1 (Kondisi terkini) & 10.4 & 1.42 & 0.57 & 0.0125 & 503.146 \\
\hline Propeller Data (Commissioning) & 12 & 2.056 & 0.82 & 0.026 & 1046.54 \\
\hline
\end{tabular}

Berdasarkan tabel di atas didapatkan bahwa nilai pitch berpengaruh terhadap performa sistem propulsi yang pada kasus ini ditandai dengan $P_{D}$ (Delivered Power). Semakin besar nilai dari pitch akan menyebabkan daya yang dikeluarkan oleh propeller semakin besar. Hal ini disebabkan karena semakin besar nilai dari pitch maka jarak yang ditempuh oleh kapal dalam satu putaran propeller semakin besar, oleh karena itu kecepatan kapal semakin meningkat dan daya $\left(P_{D}\right)$ yang dibutuhkan semakin besar. Pada Cruise1, nilai pitch maksimum adalah $1.42 \mathrm{~m}$ sedangkan pada kondisi commissioning sebesar $2.056 \mathrm{~m}$. Hal ini menunjukkan bahwa telah terjadi penurunan performa pada kapal yang ditandai dengan menurunnya kemampuan kapal untuk bergerak dengan jarak dan kecepatan tertentu. Penurunan performa tersebut dapat disebabkan oleh beberapa hal seperti usia mesin yang sudah lanjut, kualitas spare part yang kurang baik, dan perawatan mesin yang kurang optimal.

Perhitungan nilai $P_{D}$ berdasarkan metodologi yang telah diuraikan tentunya akan lebih valid jika dibandingkan dengan beberapa metode lainnya. Salah satu metode yang dapat digunakan adalah perhitungan torsi pada poros pada saat kapal berlayar dengan menggunakan torsionmeter. Dengan nilai torsi yang didapatkan, maka nilai $P_{D}$ dapat dikalkulasi menggunakan persamaan (5). Selain itu perlu untuk dikaji ulang pengaruh dari gelombang, arah dan kecepatan angin terhadap nilai pitch yang didapatkan agar dapat meningkatkan akurasi dari perhitungan performa sistem propulsi,

\section{KESIMPULAN}

Estimasi terhadap performa sistem propulsi dari kapal pada saat berlayar dapat dilakukan secara analitik. Untuk kapal dengan propeller jenis CPP, metode perhitungannya adalah dengan menggunakan data jarak dan kecepatan yang ditempuh selama satu menit untuk mendapatkan nilai pitch dari propeller pada kecepatan yang berbeda-beda. Hasil yang didapatkan bahwa metode yang dikembangkan dapat dijadikan sebagai estimasi awal untuk mengetahui performa sistem propulsi kapal dengan metode analitik secara real-time. Metode perhitungan yang dikembangkan juga dapat menilai performa sistem propulsi kapal setelah beroperasi dalam kurun waktu 
tertentu dengan membandingkan nilai pitch kondisi terkini dan nilai pitch propeller pada saat kapal selesai dibangun (commissioning) dan berdasarkan perhitungan, dinyatakan bahwa KR Baruna Jaya IV mengalami penurunan performa yang ditandai dengan penurunan nilai pitch pada saat kecepatan maksimum. Untuk meningkatkan validitas dari perhitungan, sebaiknya hasil yang telah didapat dibandingkan dengan metode perhitungan sistem propulsi secara eksperimen seperti menggunakan torsionmeter.

\section{DAFTAR PUSTAKA}

Bernitsas, M., Ray, D., dan Kinley, P. (1981). Kt Kq Eta curves -Wageningen B-Series Propellers. Department of Naval Architecture and Marine Engineering, The University of Michigan.

Chuang, Z., dan Steen, S. (2011). Prediction of Speed Loss of a Ship in Waves. In: Second International Symposium on Marine Propulsors Smp'11, Hamburg, June 11. The Institute for Fluid Dynamics and Ship Theory (FDS)-Hamburg University of Technology (TUHH), German Society for Maritime Technology (STG).

Dang, J., van den Boom, H. J. J., dan Ligtelijn, J. Th. (2013). The Wageningen C-and D-Series Propellers. In: 12th International Conference on Fast Sea Transportation FAST, Amsterdam, The Netherlands.

Holtrop, J., dan Mennen, G. G. J. (1982). An approximate power prediction method. International Shipbuilding Progress 29.335, 166-170. https://doi.org/10.3233/ISP1982-2933501.

International Maritime Organization. (2015). Third IMO GHG Study 2014 Executive Summary and Final Report. www.imo.org.

Molland, A. F., Turnock, S. R., dan Hudson, D. A. (2011). Wake and Thrust Deduction. In Ship Resistance and Propulsion: Vol. I (pp. 144-161). https://doi.org/10.1017/ CBO9780511974113.

Tsujimoto, M., Kuroda, M., Shibata, K., Sogihara, N., dan Takagi, K. (2009). On a Calculation of Decrease of Ship Speed in Actual Seas. Journal of Japan Society of Naval Architects and Ocean Engineer, 9, 79-85. https://doi.org/https://doi.org/ 10.2534/jjasnaoe.9.79.

Waskito, D. (2018). Technical Note 1_Analisa Delivered Power K.R. Baruna Jaya IV. Catatan Teknis. Balai Teknologi Survei Kelautan, Badan Pengkajian dan Penerapan Teknologi, Jakarta.1-4pp.

Zhao, F., Yang, W., Tan, W. W., Chou, S. K., dan Yu, W. (2015). An Overall Ship Propulsion Model for Fuel Efficiency Study. Energy Procedia, 75(65), 813-818. https://doi.org/10.1016/j.egypro.2015.07.139. 